\title{
Growth and biometric relationships of the pearl oyster Pinctada fucata (Gould) on transplanting from the Gulf of Mannar to the Arabian Sea
}

\author{
Kolliyil S Mohamed, Vasanth Kripa,Tharammal S Velayudhan and Kavintekizhakkathil K Appukuttan \\ Central Marine Fisheries Research Institute, Cochin, Kerala State, India
}

Correspondence: K S Mohamed, Central Marine Fisheries Research Institute, PO Box 1603, Cochin 682018, Kerala State, India. E-mail:ksmohamed@vsnl.com

\begin{abstract}
Comparative studies were made on the growth and biometric relationships of the pearl oyster Pinctada fucata (Gould) Tuticorin stock at (Tuticorin (TST) parent stock) transplanted from the Tuticorin Bay $\left(8.7^{\circ} \mathrm{N} ; 78.2^{\circ} \mathrm{E}\right)$ in the Gulf of Mannar along the Indian southeast coast to Kollam Bay $\left(8.8^{\circ} \mathrm{N} ; 76.5^{\circ} \mathrm{E}\right)$ in the Arabian Sea along the Indian southwest coast (Tuticorin stock at Kollam (TSK) - transplanted stock). At the time of transplantation, Kollam Bay did not have a native stock, however, within a year, the transplanted stock spawned and oyster spats were collected from within the farm (Kollam stock (KS) - progeny stock). The growth in dorso-ventral measurement and total weight in Kollam Bay was 1.4-1.6 times and 3.1 to 6.8 times respectively greater than that observed at Tuticorin. Furthermore, at Kollam Bay, the thickness observed at the end of first year was similar to that obtained at the end of second year in Tuticorin. Both the TSK and KS had significantly higher instantaneous growth rates (IGR) than TST. All the stocks displayed significantly different biometric relationships. The increased growth in Kollam Bay is attributed to the almost double productivity in the Arabian Sea compared with the Bay of Bengal. It is concluded that in the case of P. fucata, the site and its interaction with environment are important determinants of growth and shell dimensions. The present study clearly indicates that the environmental conditions prevailing along the southeast Arabian Sea are congenial for the growth, gametogenesis, spawning and settlement of $P$. fucata larvae. In spite of strong monsoonal influences in the hydrology of Kollam Bay, the growth and reproduc-
\end{abstract}

tion of $P$. fucata stocks indicates its relative hardiness and ability to adapt to a changed environment.

Keywords: Pinctada fucata, growth, biometry, transplant, Arabian Sea, Gulf of Mannar

\section{Introduction}

The pearl oyster Pinctada fucata (Gould) used for commercial pearl production in India has a wide distribution from the western Pacific Ocean (Korea and Southern China), Australia, Indian Ocean to Red Sea and Persian Gulf with Lessepsian migrants through Suez Canal into the Mediterranean (Gervis \& Sims 1992). The subspecies $P$. fucata martensii is found in Japan, and along the Indian coasts, the subspecies P. fucata vulgaris has a restricted distribution, limited to the southeast Bay of Bengal in the Gulf of Mannar and Palk Bay along the maritime state of Tamil Nadu, and in the Gulf of Kutch along the northeast Arabian Sea off the maritime state of Gujarat (Alagarswami 1991). Until the middle of last century these oysters were fished for oriental pearls and later, because of paucity of natural stock, the Governments of these states closed the fishery (Chacko 1970).

Detailed studies on the growth of $P$. fucata have been done in Australia (Tranter 1959); Korea (Yoo, Chang \& Lim 1986); Arabian Gulf (Mohammad 1976); P. fucata martensii in Japan (Numaguchi \& Tanaka 1986a, b); P. imbricata (Roding) in Mexico (Lodeiros, Pico, Prieto, Narvaez \& Guerra 2002) and Australia (Colgan \& Ponder 2002) have been recorded. In India, the growth of the oysters in the 
Gulf of Mannar and Palk Bay (Devanesan \& Chidambaram 1956; Chellam 1978) and in the Gulf of Kutch (Gokhale, Easwaran \& Narasimhan 1954; Narayanan \& Michael 1968; Pandya 1975) has been studied. Faster growth is advantageous for reducing preliminary grow-out phase while low growth rates favour the final coats of nacre on a pearl before harvesting.

The growth of hatchery produced pearl oyster spat transplanted to pearl farms near the natural oyster beds in the Gulf of Mannar were studied (Chellam 1978). He observed that the pearl spat (3-5 mm) produced in the hatchery have to be reared for 12-20 months before they reach an implantable size (>45 mm dorso-ventral measurement (DVM)). Currently commercial pearl culture farms in India are located along the southeast coast and one of the problems facing the industry is the long grow-out phase. In an experimental trial conducted to test the feasibility of developing pearl culture along the southwest coast, P. fucata spat and nucleated oysters were transplanted to the Arabian Sea near Cochin and observations for 6 months indicated that the growth and nacre secretion were faster along the southwest coast (Velayudhan, Kripa \& Alloycious 1999).

Growth, survival and reproduction of pearl oysters are controlled by several environmental factors namely, temperature (Numaguchi \& Tanaka 1986b; Pass, Dybdahl \& Mannion 1987), salinity (Kawamoto \& Motoki 1954; Alagarswami \& Victor 1976; Numaguchi \& Tanaka 1986a), silt load (Nayar, Mahadevan, Ramadoss, Sundaram \& Rajan 1978; Chellam, Velayudhan \& Victor 1987), currents (Kafuku \& Ikenoue 1983), food availability (Pandya 1976; Nasr 1984) and the response to these variations during different life stages like spat and adult differ (Alagarswami 1991; Gervis \& Sims 1992).

A factor which has hindered the development of pearl culture in India is the relatively small thickness (the maximum distance between external surfaces of the two valves when they are closed) of the oyster which limits the size of the nucleus $(3-5 \mathrm{~mm}$ diameter) which can be implanted and presently the commercially cultured Indian marine pearls have a diameter of less than $6 \mathrm{~mm}$. Another critical factor that determines the size of the cultured pearl is the shell dimension of the pearl oyster. Bigger nuclei can be implanted in pearl oysters with larger thickness, and therefore, shell dimensions have been used as criteria for crossbreeding of $P$. fucata martensii (Wada 1984).
The earlier transplantation trials from the Gulf of Mannar to southeast Arabian Sea have been encouraging, indicating that the environmental conditions in the transplanted site are likely to be congenial for the growth and survival of $P$. fucata. The present study was designed to explore the possibilities of developing pearl farms along the SE Arabian Sea, which can significantly reduce the growout phase in pearl culture. The objectives of the study were (1) to estimate the growth rate of P. fucata transplanted from the Gulf of Mannar to the Arabian Sea, (2) to understand the variations in biometric relationships of the transplanted stock from spat to implantable stage and (3) to determine the effect of environmental factors on the growth of pearl oysters. The transplantations were made to a semi-enclosed bay, the Kollam Bay in the southeast Arabian Sea in the maritime state of Kerala.

\section{Materials and methods}

The study was conducted from February 2001 to April 2004 in Kollam Bay, a man-made semi-enclosed bay of $6.6 \mathrm{~km}^{2}\left(8.8^{\circ} \mathrm{N} ; 76.5^{\circ} \mathrm{E}\right.$, Fig. 1), along the southwest coast of India in the Arabian Sea.

In February 2001, 5000 P. fucata spat produced in the shellfish hatchery of CMFRI at Tuticorin in the Gulf of Mannar $\left(8.7^{\circ} \mathrm{N} ; 78.2^{\circ} \mathrm{E}\right)$ were transported by road to Kollam Bay in the Arabian Sea. These spat (Tuticorin stock at Kollam (TSK)) were stocked in synthetic Velon $^{\mathrm{TM}}$ net screen bags (Mumbai, India) with a mesh size of $1 \mathrm{~mm}$ and placed in single layered square lantern cages $(30 \times 30 \mathrm{~cm})$ with a rigid $\mathrm{Ne}$ $\operatorname{tlon}^{\mathrm{TM}}$ (Mumbai, India) base of mesh size $2 \mathrm{~mm}$ and sides covered by old fish net with a webbing of $1 \mathrm{~cm}$. After the initial transit stress related mortality had reduced and stabilized, the healthy spat with a mean DVM $10.95 \pm 0.2 \mathrm{~mm}$ and total weight $0.095 \pm$ $0.013 \mathrm{~g}$ were stocked in 30 cages at a density of 125 spat per cage and were suspended from a $5 \times 5 \mathrm{~m}$ wooden raft. When the spat reached $30-40 \mathrm{~mm}$ DVM the density was reduced to 25 numbers per cage. Ten cages were tagged with plastic numbered tokens and used for monitoring the growth of the oysters. The other cages were treated as substitute replicates and oysters from these cages were used to replace the dead oysters in the experimental replicates to maintain uniform density. This stock was monitored for a period of 18 months.

The pearl oyster spat collected from Kollam Bay during December-February 2002 were considered 


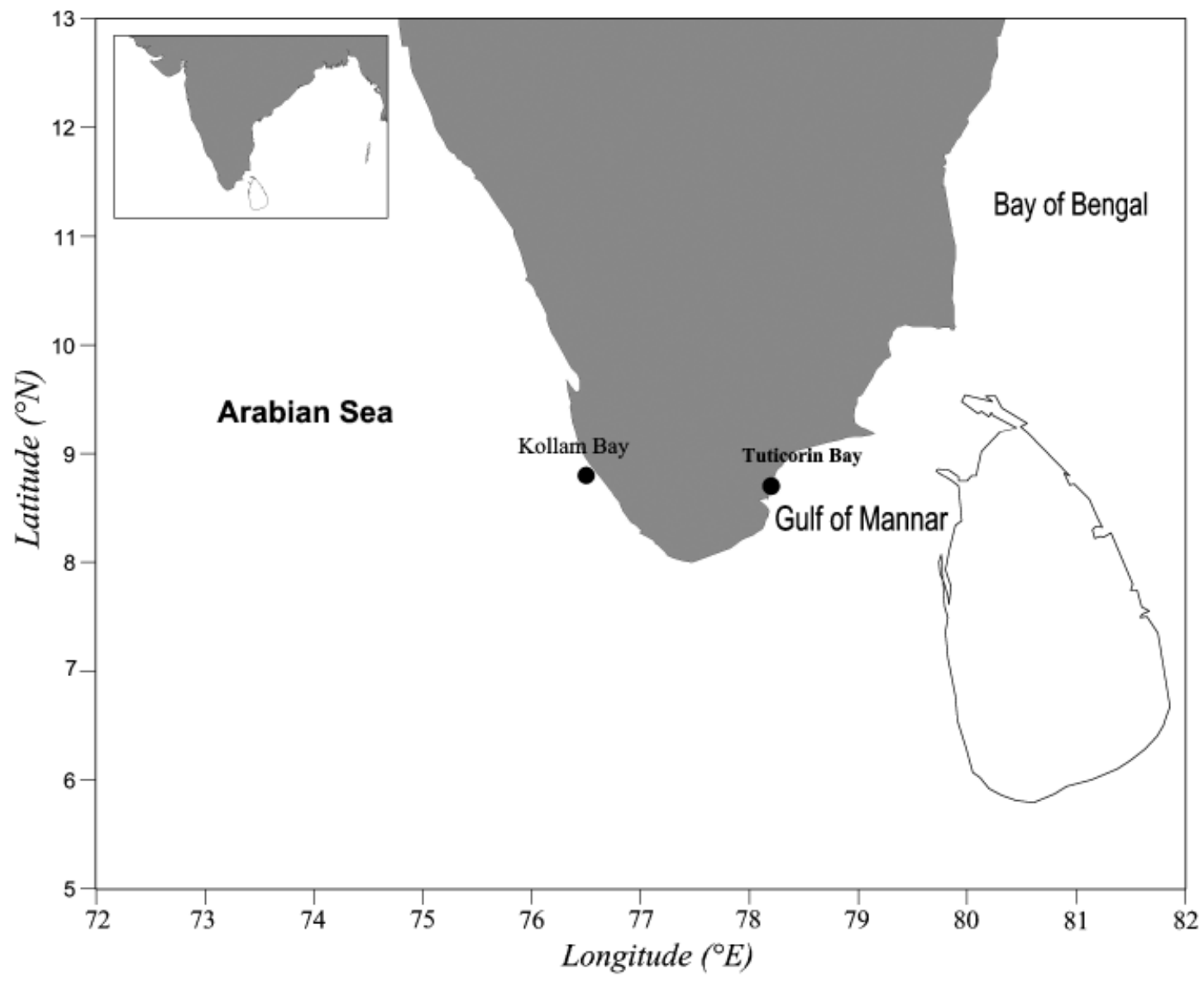

Figure 1 Map showing the Kollam Bay in the southeast Arabian Sea and Tuticorin Bay in the Gulf of Mannar from where the transplant was made.

as spat originating from the west coast and these (Kollam stock(KS)) spat with a mean length $10.36 \pm$ $2.92 \mathrm{~mm}$ and total weight $0.21 \pm 0.13 \mathrm{~g}$ were reared from February 2002 for 17 months from the same raft under the same rearing conditions as for the transplanted spat TSK.

Growth of the pearl oysters was estimated from the changes in the DVM, hinge length (HL), thickness (THK) and total live weight (TWT). To document growth, 10 oysters from each numbered replicate cage $(n=100)$ were randomly collected at monthly intervals and measured. The fouling on the oysters were carefully scraped off taking care not to damage the growth processes and gently washed to remove the silt. Shell dimensions of the oysters, excluding the growth processes were measured using a digital Vernier calipers ( $0.01 \mathrm{~mm}$ precision) and the total weight by a portable electronic balance ( $0.01 \mathrm{~g}$ precision).

For comparison of the growth characteristics of P. fucata reared in the Gulf of Mannar (Tuticorin stock at Tuticorin (TST)), the data collected by one of the authors (T. S. V.) by rearing the spat produced in the hatchery using stock in the pearl farm in Tuticorin Bay in Gulf of Mannar during 1987 to 1989 was used. The culture methods were similar to that of the present study and described by Chellam (1988). The hydrological factors (temperature, salinity, total suspended solids, chlorophyll $a$ and rainfall) documented (by T.S. Velayudhan) during the period were also used.

The mean and standard error were calculated from the observed individual measurements of the replicates. These means were used to calculate the absolute growth rate (AGR) and the instantaneous growth rate (IGR), which does not have time restriction (Hopkins 1992). The AGR was calculated by the formula

$$
A G R=\frac{L_{t}-L_{i}}{t}
$$


where, $L_{i}$ is the initial length and $L_{t}$ the final length after time $t$. The IGR was computed from the formula

$$
I G R=\frac{L n_{t}-L n_{i}}{t}
$$

where $L n_{t}$ is the natural log of the length at time $t$ and $L n_{i}$ is the natural log of the initial length.

For the comparison of IGRs during different growth stages of the pearl oyster, the data were grouped into eight length classes of $10 \mathrm{~mm}$ class interval $(1-10,11-20,21-30,31-40,41-50,51-60,61-$ 70 and $71-80 \mathrm{~mm}$ ). The length group wise IGRs between different stocks were compared using ANOvA. In case of significant differences, Duncan's multiple range test (DMRT) was carried out to find out the significantly different means at 5\% level using SPSS VER. 8.0 software.

For studying the variation in the relationships between different shell dimensions during various growth stages, the individual dimensional measurements of each stock were grouped into four length classes namely, 1-20, 21-40, 41-60 and 61-80 mm. The biometric relations (DVM-TWT, DVM-HL, DVMTHK) of $P$. fucata in each group were analysed by the least-square method employing the equation, $y=$ $a+b x$, where $a$ is the intercept and $b$ the slope. When the relationships were not linear, as for DVM on TWT, the regression equation was fitted after logarithmic transformation. The equality of slopes and intercepts among different stocks were tested using analysis of covariance, ANCova (Snedecor \& Cochran 1967).

The hydrological parameters in the farm were documented at monthly intervals during the study period. Water samples were collected from the farm site at a depth of $1.5 \mathrm{~m}$ using $10 \mathrm{~L}$ Niskin bottles. Water temperature was recorded by a thermometer with $0.5^{\circ} \mathrm{C}$ precision and salinity by a refractometer. In the laboratory, water samples were screened through a $200 \mu \mathrm{m}$ mesh net to remove larger zooplankton and debris. This was then filtered on to pre-washed, precombusted $\left(450{ }^{\circ} \mathrm{C}, 4 \mathrm{~h}\right)$ and pre-weighed Whatman $\mathrm{GF} / \mathrm{F}$ filters ( $0.45 \mu \mathrm{m}$ nominal pore size) to analyse total suspended solids (TSS, $\mathrm{mg} \mathrm{L}^{-1}$ ) and photosynthetic pigments (chlorophyll $a, b$ and $c$ ). The TSS determination was carried out gravimetrically after desiccation $\left(105^{\circ} \mathrm{C}, 24 \mathrm{~h}\right)$ using an electronic balance (accuracy $\pm 0.1 \mathrm{mg}$ ). Chlorophyll pigments and nutrients (nitrate, nitrite, silicate and phosphate) were measured using a spectrophotometer (Strickland \& Parsons 1972).
The correlation between temporal changes in hydrological parameters at Tuticorin Bay and Kollam Bay and the AGR in DVM and TWT were analysed by means of Spearman's correlation using SPSS VER. 8.0 software.

\section{Results}

\section{Growth rates}

The comparison of changes in DVM, HL, THK and TWT over time in different stocks is shown in Fig. 2. Both TSK (transplanted) and KS (native) had higher growth in length dimensions and weight than TST. The differences were pronounced in the case of DVM,THK and TWT and not so high in the case of HL.

After a period of 6 months, the DVM reached 55.0, 45.7 and $41.3 \mathrm{~mm}$ in the case of TSK, KS and TST respectively (Table 1). Moreover, these differences were further increased after a period of 1 year. The HL also reached higher values for TSK and KS in comparison with TST after 6 months, though the differences in KS and TST were not very large. However after 1 year, the differences in HL were prominent and the difference between TST and KS and TST and TSK was about $15 \mathrm{~mm}$. In the case of THK also a similar trend was observed with the values after 1 year for KS and TSK being much higher than TST (10 mm difference).

In the case of TWT, at the end of 6 months the live weight attained by KS and TSK was almost double that of TST and the differences were more than 3 times after 1 year (Table 1). Fluctuations were observed in the TWT of KS and TSK and these were consistent with the build up of gonadal tissue during the immediate post monsoon (October-November) and pre-monsoon (May). Subsequently, weight loss due to spawning was observed in late post monsoon (December-January) and monsoon (June-July). However in the case of TST such fluctuations in TWT were not observed.

A comparison of IGRs of the DVM, HL, THK and TWT of all the three stocks among different length groups showed high rates initially followed by a decreasing trend with increase in size (Fig. 3). Irrespective of the size, the DVM-IGR of pearl oysters were higher in the Kollam Bay than at Tuticorin. The DVM-IGRs of the first three size groups and 51-70 size groups was highest in transplanted stock TSK while in the 31-50 size group, KS showed better performance than TSK (Table 2).

Multiple range comparison of the DVM-IGRs of the three stocks showed that IGR of the smallest size 



Figure 2 Plot of changes in dorso-ventral measurement (DVM), hinge length (HL), thickness (THK) and total weight (TWT) over time for the three stocks (KS,TSK and TST). 
Table 1 Dorso-ventral measurement (DVM), hinge length (HL), thickness (THK) and total weight (TWT) of different stocks after 6 months and 1 year of growth (all length measurements in $\mathrm{mm}$ and weight in $\mathrm{g}$ )

\begin{tabular}{lllllr}
\hline Period & Stock & DVM & HL & THK & TWT \\
\hline After 6 months & KS & 45.68 & 39.00 & 15.96 & 13.65 \\
& TSK & 55.01 & 45.22 & 19.09 & 20.82 \\
& TST & 41.31 & 37.18 & 13.77 & 8.99 \\
After 12 months & KS & 62.46 & 53.64 & 26.52 & 46.10 \\
& TSK & 69.80 & 55.17 & 26.98 & 56.94 \\
& TST & 43.90 & 40.88 & 16.78 & 15.96 \\
\hline
\end{tabular}

KS, Kollam stock; TSK, Tuticorin stock at Kollam; TST, Tuticorin stock at Tuticorin.

group 1-10 mm of the KS and TST were similar while that of TSK was higher and significantly different $(P<0.05)$ from the other two stocks (Table 2). The IGR of theTSK spat immediately after transplantation increased by four times than that observed for the same stock at Tuticorin in the Gulf of Mannar. After this spurt in growth, which was not observed in the succeeding generation (KS), the DVM-IGRs decreased steadily with increase in size. A similar but smaller spurt was observed for TST from 11 to 20 to 21 to $30 \mathrm{~mm}$ size group.

In the 31-40 mm size group DVM-IGRs were significantly $(P<0.05)$ different among the three stocks and was three times higher in KS than that observed at Tuticorin in the Gulf of Mannar (Table 2). The IGRs became negative in the $51-60 \mathrm{~mm}$ length range for TST while the KS and TSK continued to grow indicating that the environmental conditions favoured the growth of the oysters. With increase in size, the growth rates were similar for the transplanted stock (TSK) and its progeny (KS).

The IGR in HL was higher (by 31 times) in TSK in the 11-20 size group compared with that of TST. In the case of TST an increase in HL-IGR was observed upon reaching 21-30 mm size. With increase in size, the HL-IGRs decreased steadily for all the stocks and reached negative values at $51-60 \mathrm{~mm}$ for TST. The pearl oysters continued to grow at Kollam Bay and HL-IGRs became negative only in the size range 71$80 \mathrm{~mm}$ for KS. Comparison of the HL-IGRs of the three stocks showed that the rates of KS and TST were similar while that of transplanted stock was significantly higher $(P<0.05)$ from other two during the initial stages (1-30 mm). In the oysters above $41 \mathrm{~mm}$ the HL-IGRs of all the three stocks were similar.

The THK-IGRs of oysters showed a decreasing trend with increasing sizes with a sharp spurt in 11 to $20 \mathrm{~mm}$ size group for TSK and 21 to $30 \mathrm{~mm}$ size group for TST.

Among the different stocks, theTHK-IGRs were significantly different $(P<0.05)$ for $11-20,31-40$ and 41-50 for TSK and 11-20 size groups for TST. All other THK-IGRs were similar for all size groups for all stocks.

Unlike the length-related IGRs, the TWT-IGRs of the three stocks showed wide variations without a clear trend. The TWT-IGRs of the three stocks in the 1 to $10 \mathrm{~mm}$ size group were significantly different $(P<0.05)$. Total live weight-instantaneous growth rates were observed to be significantly different $(P<0.05)$ in the $11-20$ and $41-50 \mathrm{~mm}$ size groups for KS and 31-40 mm size group for TSK.

\section{Biometric relationships}

Linear regressions of DVM with TWT, HL and TWT are shown in (Fig. 4) along with corresponding results of ANCOVA in Table 3. All regression slopes and intercepts showed significant differences among the different length groups and stocks with some exceptions.

The log DVM-TWT relationship showed that the rate of increase in weight with respect to length was significantly lower $(P<0.05)$ for TST in comparison with TSK and KS for 1-20 mm length group. In the 20-40 mm length group also these relationships were significant except in the case of TST vs. KS. However, with increase in length, an increase in intercept values were observed with a corresponding decrease in slopes (Fig. 4). With increase in length, the corresponding weights were relatively higher in TSK and KS.

The DVM-HL relationships did not show any significant differences $(P>0.05)$ in slopes in the $1-20$ length groups and thereafter the relationships were significantly different $(P<0.05)$ in $20-40$ and 40 $60 \mathrm{~mm}$ length groups. These relationships were not significantly different between TST and KS in 20-40 and between TSK and KS in $60-80 \mathrm{~mm}$ group. In general, the initial lengths (intercepts) were significantly different for all groups. Although, initially the rate of increase in HL with respect to DVM did not show significant differences $(P>0.05)$ in the $1-20 \mathrm{~mm}$ length group, on reaching $40-60 \mathrm{~mm}$ lengths, the slopes and intercepts of all three stocks were significantly different $(P<0.05)$. On attaining 60-80 mm lengths, the HLs of both parent and progeny stocks at Kollam Bay were similar. 

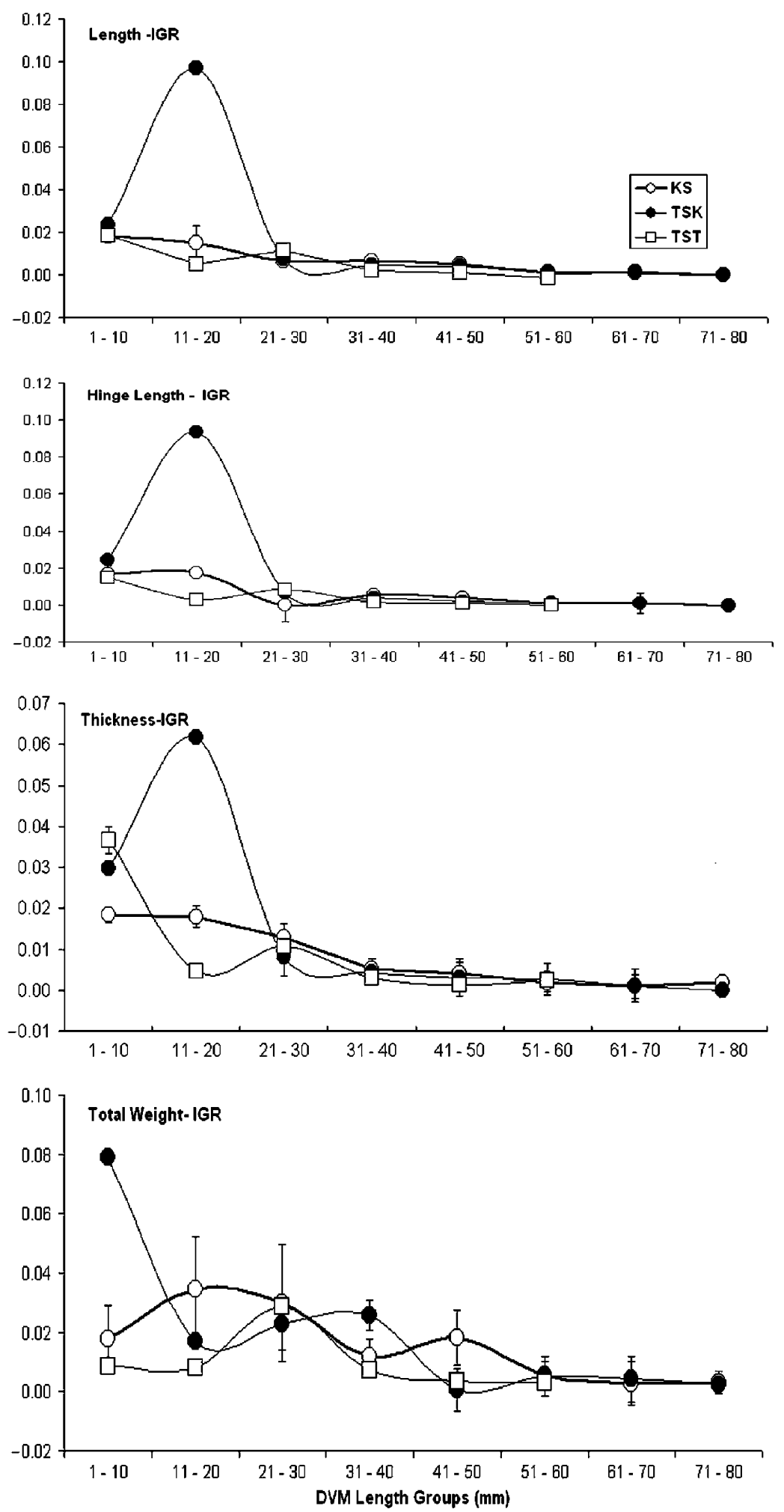

Figure 3 Comparison of instantaneous growth rates (IGRs) in dorso-ventral measurement (DVM), hinge length (HL), thickness (THK) and total weight (TWT) in different DVM length groups in the three stocks. 
Table 2 Results of ANCOVA for testing equality of slopes and intercepts

\begin{tabular}{|c|c|c|c|c|c|c|c|}
\hline $\begin{array}{l}\text { Length } \\
\text { group }\end{array}$ & $\begin{array}{l}\text { Parameters } \\
\text { compared }\end{array}$ & $\begin{array}{l}\text { Stocks } \\
\text { compared }\end{array}$ & $N$ & $\begin{array}{l}F \text { value } \\
\text { of slope }\end{array}$ & $\begin{array}{l}\text { Significance } \\
\text { at } 5 \%\end{array}$ & $\begin{array}{l}\text { F value } \\
\text { of intercept }\end{array}$ & $\begin{array}{l}\text { Significance } \\
\text { at } 5 \%\end{array}$ \\
\hline $1-20$ & DVM-TWT & TST vs. TSK & 95 & 3.49 & $S$ & 323.7 & $S$ \\
\hline $1-20$ & DVM-TWT & TSK vs. KS & 54 & 0.93 & NS & 2.24 & NS \\
\hline $1-20$ & DVM-TWT & TST vs. KS & 109 & 5.50 & $\mathrm{~S}$ & 618.73 & $S$ \\
\hline $1-20$ & DVM-HL & TST vs. TSK & 95 & 2.28 & NS & 180.17 & $S$ \\
\hline $1-20$ & DVM-HL & TSK vs. KS & 54 & 1.37 & NS & 3.90 & $S$ \\
\hline $1-20$ & DVM-HL & TST vs. KS & 109 & 19.17 & NS & 78.65 & $S$ \\
\hline $1-20$ & DVM-THK & TST vs. TSK & 95 & 0.09 & NS & 9.35 & $S$ \\
\hline $1-20$ & DVM-THK & TSK vs. KS & 54 & 17.02 & $S$ & 74.61 & $S$ \\
\hline $1-20$ & DVM-THK & TST vs. KS & 109 & 37.23 & $S$ & 964.74 & $S$ \\
\hline $20-40$ & DVM-TWT & TST vs. TSK & 352 & 812.72 & $S$ & 1690.0 & $S$ \\
\hline $20-40$ & DVM-TWT & TSK vs. KS & 100 & 274.60 & $S$ & 126.46 & $S$ \\
\hline $20-40$ & DVM-TWT & TST vs. KS & 350 & 1.30 & NS & 12.45 & $S$ \\
\hline $20-40$ & DVM-HL & TST vs. TSK & 354 & 4.03 & $S$ & 25.46 & $S$ \\
\hline $20-40$ & DVM-HL & TSK vs. KS & 100 & 5.82 & $S$ & 24.69 & $S$ \\
\hline $20-40$ & DVM-HL & TST vs. KS & 350 & 0.21 & NS & 22.78 & $S$ \\
\hline $20-40$ & DVM-THK & TST vs. TSK & 354 & 442.11 & $S$ & 1103.85 & $S$ \\
\hline $20-40$ & DVM-THK & TSK vs. KS & 100 & 7.81 & $S$ & 3.73 & $S$ \\
\hline $20-40$ & DVM-THK & TST vs. KS & 350 & 16.69 & $S$ & 58.63 & $S$ \\
\hline $40-60$ & DVM-TWT & TST vs. TSK & 552 & 14.38 & $S$ & 2.95 & $S$ \\
\hline $40-60$ & DVM-TWT & TSK vs. KS & 265 & 229.76 & $S$ & 406.87 & $S$ \\
\hline $40-60$ & DVM-TWT & TST vs. KS & 513 & 688.49 & $S$ & 918.79 & $S$ \\
\hline $40-60$ & DVM-HL & TST vs. TSK & 552 & 3.69 & $S$ & 319.51 & $S$ \\
\hline $40-60$ & DVM-HL & TSK vs. KS & 265 & 1.02 & $S$ & 637.03 & $S$ \\
\hline $40-60$ & DVM-HL & TST vs. KS & 513 & 5.85 & $S$ & 4.55 & $S$ \\
\hline $40-60$ & DVM-THK & TST vs. TSK & 552 & 11.68 & $S$ & 5955.8 & $S$ \\
\hline $40-60$ & DVM-THK & TSK vs. KS & 265 & 58.69 & $S$ & 1405.73 & $S$ \\
\hline $40-60$ & DVM-THK & TST vs. KS & 513 & 86.71 & $S$ & 1347.43 & $S$ \\
\hline $60-80$ & DVM-TWT & TST vs. TSK & 195 & 263.77 & $S$ & 176.0 & $S$ \\
\hline $60-80$ & DVM-HL & TST vs. TSK & 195 & 0.27 & NS & 531.54 & $S$ \\
\hline $60-80$ & DVM-THK & TST vs. TSK & 195 & 21.25 & $\mathrm{~S}$ & 849.63 & $S$ \\
\hline
\end{tabular}

Dorso-ventral measurement (DVM), hinge length (HL), thickness (THK) and total weight (TWT). Stocks compared: Tuticorin stock at Tuticorin (TST), Tuticorin stock at Kollam (TSK) and Kollam stock (KS).

The most profound effect on transplanting P. fucata was found in the DVM-THK relationship. although initially,TST and TSK did not show any significant difference $(P>0.05)$ in this relationship; from 20 to $40 \mathrm{~mm}$ onwards, both KS and TSK showed higher rate of increase in thickness with increase in length than TST (Fig. 4). Furthermore, between TSK and KS the latter showed higher rate of increase in thickness.

\section{Hydrological parameters}

Variations in select hydrological parameters of Tuticorin Bay and Kollam Bay are shown in Figs 5-7. At Tuticorin Bay in the Gulf of Mannar the salinity did not show much fluctuation but showed a decrease in November, December and January (Fig. 5) coinciding with the peak winter monsoon (Fig. 7). Temperature also showed a similar trend with a peak in summer months of April and July (Fig. 5). The TSS values showed a minor peak in February and July and thereafter showed an increasing trend from September to December. Chlorophyll $a$ values showed peak values during June-July (summer) and again during winter monsoon. At Kollam Bay salinity values fluctuated between 28 and 35 ppt (Fig. 6) with peak during summer and again in September-November. The values were consistently low during the summer monsoon, June-August. TSS values showed high fluctuations and peaked during April (summer) and July (monsoon). Temperature showed a decrease during both the summer monsoon (July-August) and winter monsoon (October) coinciding with peak rainfall during July and October (Fig. 7). Productivity values remained very low during February-June and started increasing with the onset of monsoon and 
climbed to a peak in October (winter monsoon). Phosphate values fluctuated with peak in April and June coinciding with pre-monsoon and monsoon (Fig. 7). There was marked difference in the rainfall pattern and intensity between the two sites. At Kollam Bay both the summer and winter monsoon were dominant (Fig. 7) with the summer monsoon averaging $370 \mathrm{~mm}$ in July and $430 \mathrm{~mm}$ in October. While at Tuticorin Bay, the rainfall was comparatively less intense and peaked during October (average $55 \mathrm{~mm}$ ).

The environmental parameters at both Tuticorin Bay and Kollam Bay were correlated with AGR and the results are shown in Table 4. While rainfall was positively correlated with growth in Tuticorin Bay, it was very significantly negatively correlated at Kollam
Bay. Other parameters showing significant correlations were TSS - negatively in Tuticorin Bay; phosphate and temperature positively and net productivity and chlorophyll $b$ negatively at Kollam Bay.

\section{Discussion}

Movement of bivalves, especially pearl oysters as transfers and outside introductions (Gervis \& Sims 1992; Pit \& Southgate 2003), within their geographical range has been attempted in the last century, leading either to an establishment of transplanted populations or failures even after repeated trials. An
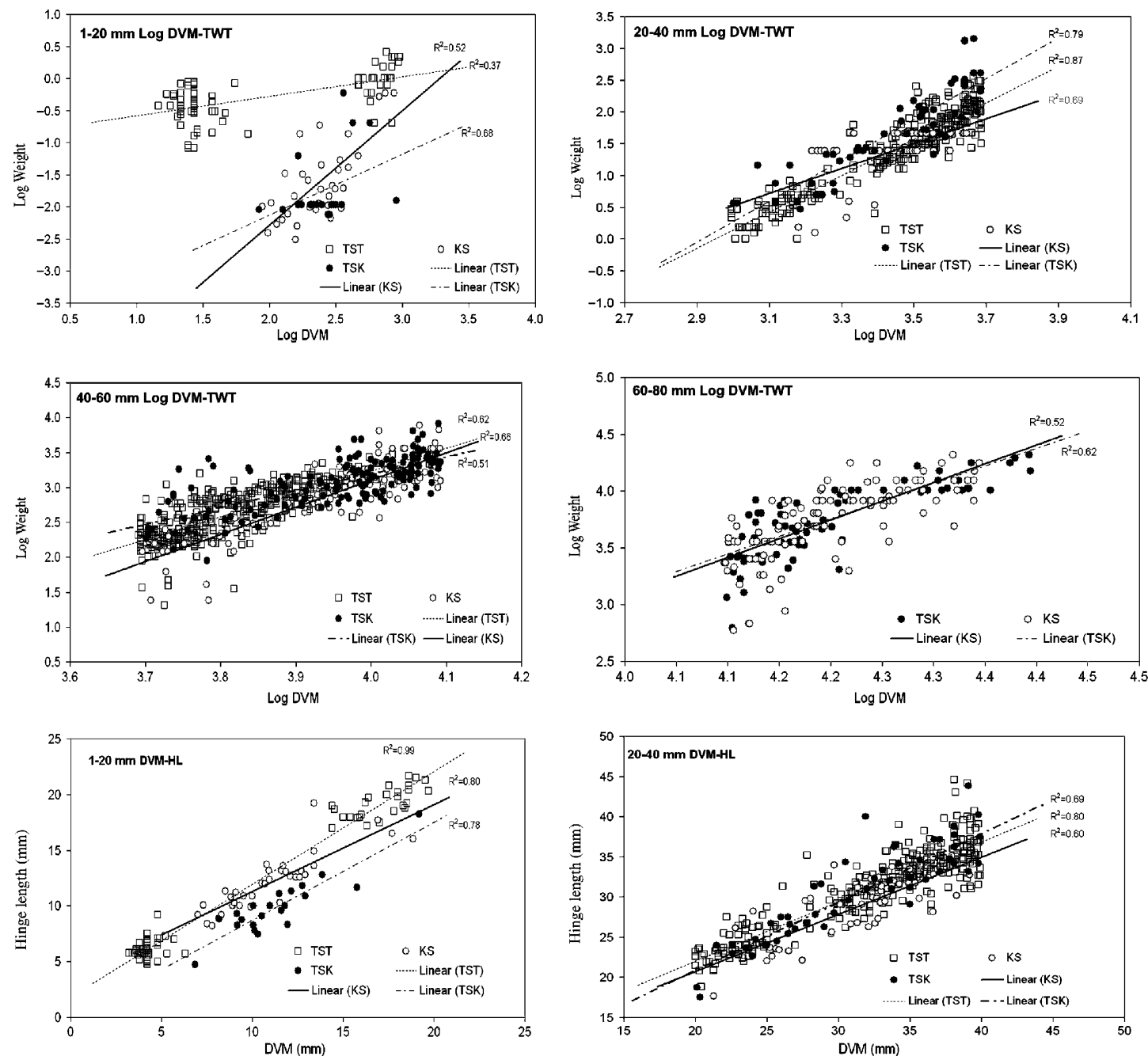

Figure 4 Regression lines fitted for showing relationships between different shell dimensions and total weight in various length groups. $R^{2}$ values are indicated close to the fitted line. 

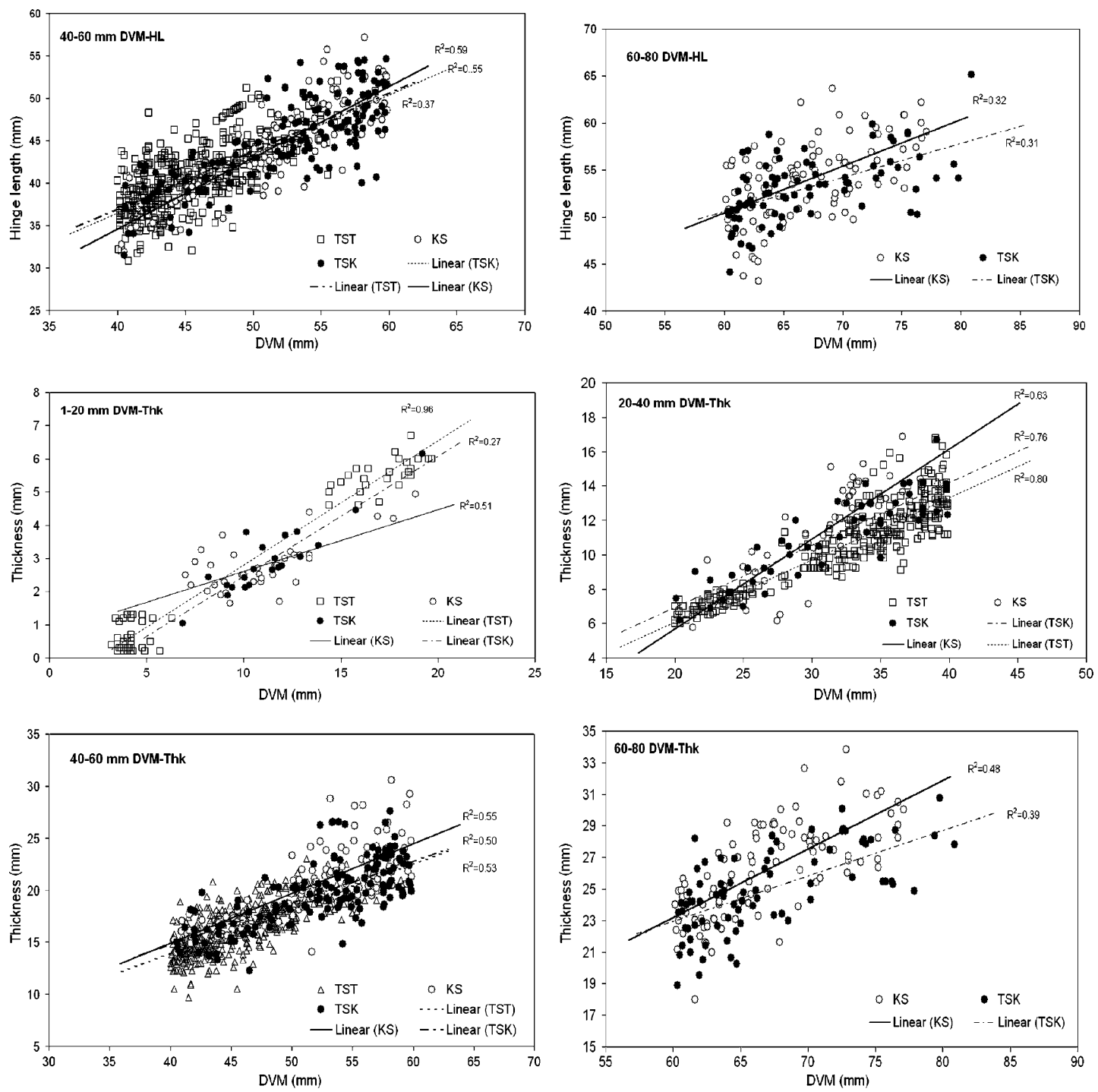

Figure 4 Continued.

attempt to introduce P. fucata martensii to Morocco failed (Beaubrun 1972). In the present study transplanting the pearl oyster $P$. fucata from Tuticorin Bay in the Gulf of Mannar $\left(8.8^{\circ} \mathrm{N} ; 76.5^{\circ} \mathrm{E}\right)$ along the east coast of India to a semi enclosed artificial bay in the Arabian Sea along the southwest coast of India $\left(8.7^{\circ} \mathrm{N} ; 78.2^{\circ} \mathrm{E}\right)$ led to the establishment of a faster growing and reproductively active stock with more convexity (thickness). Generally, the success and failures of transplantations largely depends on the several exogenous factors particularly physicochemical parameters of the growing environment. The introduction of P. maxima to Suwarrow lagoon in the Cook Islands in 1904 was apparently successful with spat- fall being recorded within 6 months of transplantation (Saville-Kent 1905). However by 1912, this stock was severely depleted by a hurricane.

In the present study the transplanted P. fucata spawned and it was possible to collect more than 5000 spat during 2002, however, in the succeeding year the spawning intensity was low and it was possible to collect only few hundred spats from the cages. Again, in 2004 the spawning intensity was high and more than 10000 spat could be collected. Although detailed investigations on the benthic populations to assess the recruitment into the natural biota were not made, the local fishers reported incidents of occurrence of pearl oysters in the mussel populations 
Table 3 Mean instantaneous growth rates (IGR) values of dorso-ventral measurement (DVM), hinge length (HL), thickness (THK) and total weight (TWT) in different length ranges in different stocks. Results of Duncan's multiple range test (DMRT) are shown as superscripts. Non-identical superscripts row-wise indicate significant differences $(P<0.05)$

\begin{tabular}{|c|c|c|c|}
\hline $\begin{array}{l}\text { Length Range } \\
(\mathrm{mm})\end{array}$ & KS & TSK & TST \\
\hline \multicolumn{4}{|l|}{ DVM } \\
\hline $1-10$ & $0.0179^{\mathrm{a}}$ & $0.0235^{\mathrm{b}}$ & $0.0185^{a}$ \\
\hline $11-20$ & $0.0148^{\mathrm{a}}$ & $0.0971^{\mathrm{b}}$ & $0.0049^{c}$ \\
\hline $21-30$ & $0.0064^{\mathrm{a}}$ & $0.0074^{a}$ & $0.0117^{\mathrm{b}}$ \\
\hline $31-40$ & $0.0063^{a}$ & $0.0045^{\mathrm{b}}$ & $0.0021^{\mathrm{C}}$ \\
\hline $41-50$ & $0.0049^{b}$ & $0.0039^{a}$ & $0.0011^{a}$ \\
\hline $51-60$ & $0.0011^{\mathrm{a}}$ & $0.0015^{\mathrm{a}}$ & $-0.0014^{b}$ \\
\hline $61-70$ & 0.0012 & 0.0016 & \\
\hline $71-80$ & 0.0002 & 0 & \\
\hline \multicolumn{4}{|l|}{$\mathrm{HL}$} \\
\hline $1-10$ & $0.0168^{a}$ & $0.0243^{b}$ & $0.0150^{a}$ \\
\hline $11-20$ & $0.0175^{\mathrm{a}}$ & $0.0937^{b}$ & $0.0030^{a}$ \\
\hline $21-30$ & $-0.0002^{\mathrm{a}}$ & $0.0063^{\mathrm{ab}}$ & $0.0085^{a}$ \\
\hline $31-40$ & $0.0052^{\mathrm{b}}$ & $0.0038^{\mathrm{a}}$ & $0.0017^{\mathrm{a}}$ \\
\hline $41-50$ & $0.0037^{a}$ & $0.0020^{\mathrm{a}}$ & $0.0008^{a}$ \\
\hline $51-60$ & $0.0012^{\mathrm{a}}$ & $0.0015^{\mathrm{a}}$ & $-0.0002^{a}$ \\
\hline $61-70$ & 0.0008 & 0.0008 & \\
\hline $71-80$ & -0.0008 & 0 & \\
\hline \multicolumn{4}{|l|}{ THK } \\
\hline $1-10$ & $0.0183^{\mathrm{a}}$ & $0.0298^{\mathrm{a}}$ & $0.0365^{a}$ \\
\hline $11-20$ & $0.0179^{\mathrm{a}}$ & $0.0616^{\mathrm{b}}$ & $0.0046^{c}$ \\
\hline $21-30$ & $0.0129^{b}$ & $0.0082^{\mathrm{a}}$ & $0.0107^{b}$ \\
\hline $31-40$ & $0.0053^{\mathrm{a}}$ & $0.0044^{\mathrm{ab}}$ & $0.0029^{a}$ \\
\hline $41-50$ & $0.0040^{\mathrm{a}}$ & $0.0030^{\mathrm{ab}}$ & $0.0012^{a}$ \\
\hline $51-60$ & $0.0019^{a}$ & $0.0027^{\mathrm{a}}$ & $0.0024^{a}$ \\
\hline $61-70$ & 0.0009 & 0.0012 & \\
\hline $71-80$ & 0.0018 & 0 & \\
\hline \multicolumn{4}{|l|}{ TWT } \\
\hline $1-10$ & $0.0176^{\mathrm{a}}$ & $0.0790^{\mathrm{b}}$ & $0.0085^{c}$ \\
\hline $11-20$ & $0.0344^{b}$ & $0.0171^{\mathrm{a}}$ & $0.0083^{a}$ \\
\hline $21-30$ & $0.0230^{\mathrm{a}}$ & $0.0228^{a}$ & $0.0285^{a}$ \\
\hline $31-40$ & $0.0120^{\mathrm{a}}$ & $0.0258^{b}$ & $0.0072^{a}$ \\
\hline $41-50$ & $0.0181^{\mathrm{b}}$ & $0.0005^{\mathrm{a}}$ & $0.0034^{\mathrm{a}}$ \\
\hline $51-60$ & $0.0054^{\mathrm{a}}$ & $0.0051^{\mathrm{a}}$ & $0.0029^{a}$ \\
\hline $61-70$ & 0.0028 & 0.0042 & \\
\hline $71-80$ & 0.0032 & 0.0022 & \\
\hline
\end{tabular}

KS, Kollam stock; TSK, Tuticorin stock at Kollam; TST, Tuticorin stock at Tuticorin.

in the Bay. However blooms of Noctiluca and Cocchlodinium species in September 2003 and 2004 respectively, affected pearl oysters more than other bivalves like the mussel Perna viridis occurring in the same area. Although such natural calamities can severely affect $P$. fucata stock, it is quite clear that Kollam Bay in the Arabian Sea, which earlier did not have any na- tive stock of pearl oysters, is a congenial environment for the growth and reproduction of P. fucata.

In bivalves, normal growth is characterized by fast initial growth and in all the three stocks of $P$. fucata studied presently such higher growth rates in the juvenile phase were observed. In transplanted stock higher initial growth rates have been reported for P. fucata (O'Connor 2002) during the nursery and grow-out phase in Queensland waters. The growth in DVM observed presently is 1.4-1.6 times than that observed in the Gulf of Mannar and Gulf of Kutch respectively. On the other hand the growth in TWT observed in TSK and KS was 3.1-6.8 times than that observed in Gulf of Mannar and Gulf of Kutch (Table 5).

Pinctada fucata has been described as the most convex of all species of pearl oysters with an increase in the ratio of THK:DVM with age (Hynd 1955). Chellam (1988) observed a thickness of $19 \mathrm{~mm}$ in the first year, $27.1 \mathrm{~mm}$ in the second year and $31.8 \mathrm{~mm}$ at the end of third year for P. fucata in Gulf of Mannar. In the Gulf of Kutch, P. fucata attained $21.8 \mathrm{~mm}$ thickness at the end of second year and $25 \mathrm{~mm}$ at the end of third year (Gokhale et al. 1954). At Kollam Bay, the thickness obtained at the end of first year is similar to that obtained at the end of second year at Gulf of Mannar and Gulf of Kutch. The natural and hatchery bred P. fucata stocks along the Gulf of Mannar and Kutch coasts are less convex, which restricts the size of the nucleus, which could be implanted within the oyster. The advantage of larger thickness in pearl oysters is that this determines the size of the nucleus, which can be implanted for pearl production. Initial trials for large pearl (7-8 mm diameter) production at Kollam Bay using oysters grown in the bay were also successful (Kripa, Mohamed, Velayudhan, Radhakrishnan, Alloycious, Mohan \& Appukuttan 2003) with shorter time (4 months) required for complete nacre deposition.

All three stocks had significantly different IGRs as they progressed through different size groups. The transplanted stock, TSK showed a steep spurt in growth rate immediately on transplantation and maintained this increased growth rate until the close of experiment.While, KS did not show any such spurt in growth, but they showed superior growth compared with the original TST. The TST also showed a similar but smaller spurt in growth when stocked in the farm from the hatchery at $20 \mathrm{~mm}$ DVM. Evidently a sudden change to a favourable growing environment acts to spur growth performances probably due to increased availability of food indicating an 

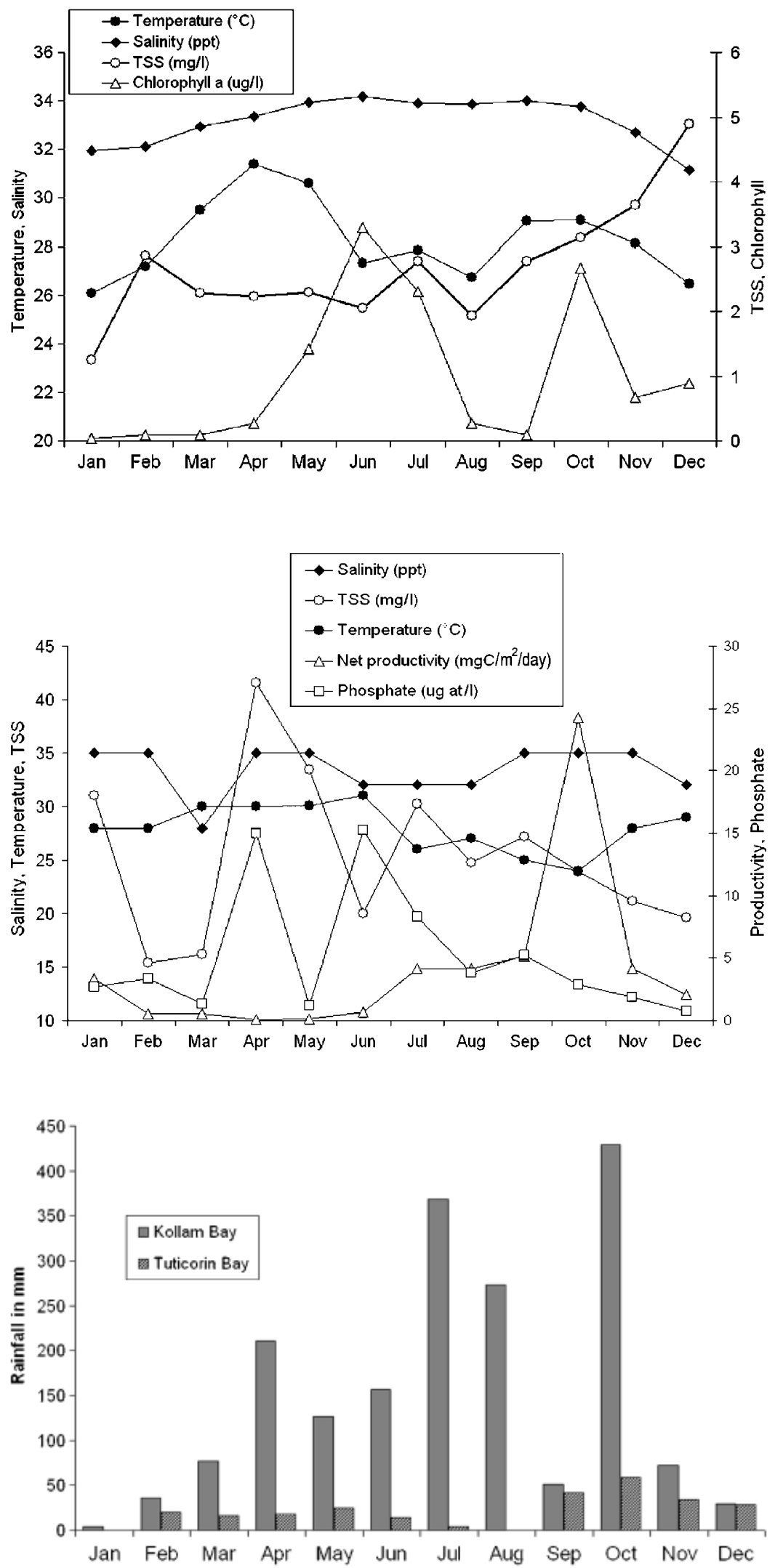

Figure 5 Variations in mean monthly hydrological parameters (selected) in Tuticorin Bay.

Figure 6 Variations in mean monthly hydrological parameters (selected) in Kollam Bay.

Figure 7 Variations in mean monthly rainfall (mm) in Kollam and Tuticorin Bays. 
immediate transplant effect. Several reports show the very high primary productivity values in the Arabian Sea as it is a tropical upwelling ecosystem. A comparison between the productivity up to $50 \mathrm{~m}$ depth in the Arabian Sea and the Bay of Bengal has shown that the average primary productivity in the Arabian Sea is $1200 \mathrm{mg} \mathrm{C} \mathrm{m}^{-2}$ day $^{-1}$ while that in the Bay of Bengal is $680 \mathrm{mg} \mathrm{C} \mathrm{m}^{-2}$ day $^{-1}$ (Nair \& Gopinathan 1981). The productivity values in the Arabian Sea are thus quite high compared with several other seas of the world (Rajagopalan \& Krishnakumar 2003).

Wada (1984) observed that shell shape and size are inheritable in P. fucata martensii and that the stocks in different locations in Japan are genetically different. However, when a genetically similar stock was grown in two different locations as in the present study, the stock in a more nutritionally rich environment outgrew the parent stock. The importance of environment over genetic factors was also reported by Stirling and Okumus (1994), when they evaluated

Table 4 Correlation coefficients of absolute growth rates (AGR) in length with environmental variables in the two different sites

\begin{tabular}{lcc}
\hline & \multicolumn{2}{l}{ Site } \\
\cline { 2 - 3 } Environmental variables & Tuticorin Bay & Kollam Bay \\
\hline Rainfall & 0.638 & -0.791 \\
& $(0.019)$ & $(0.004)$ \\
Total suspended solids & -0.531 & - \\
& $(0.048)$ & \\
Phosphate & & 0.661 \\
& & $(0.027)$ \\
Temperature & & 0.637 \\
& & $(0.035)$ \\
Net productivity & & -0.570 \\
& & $(0.043)$ \\
Chlorophyll $b$ & & -0.60 \\
& & $(0.05)$ \\
\hline
\end{tabular}

$P$ values are given brackets. the growth rates of cross-transplanted populations of the mussel Mytilus edulis in two lochs along the west coast of Scotland. In general, results of this study are in accordance with the conclusions of various authors (Mallet \& Carver 1989; Kautsky, Johannesson \& Tendengren 1990) working on M. edulis, who found that site and its interactions with the environment are major determinants of growth. However, Wada (1984) reported that both environment and genetic factors influence shell characteristics.

The TWT-IGRs showed wide variations with size and age. While in the case of TST the sudden increase observed could be due to transfer of stock from hatchery to farm, in the case of TSK and KS it is most likely to be due to the influence of gonad development and spawning. The major spawning period for P. fucata in Kollam Bay was observed to be December-January and a large number of spat could be collected on spat collectors during January-February. Although a minor spawning took place in June-July, spats could not be collected from this spawning. Similar fluctuations in total weight were not observed in TST. Earlier work by Chellam (1988) and Velayudhan, Chellam, Dharmaraj, Victor and Kasim (1996) reported that although hatchery produced spat were grown to adult size in raft farms in Tuticorin Bay in the Gulf of Mannar, no spawning was observed. The reproductive seasonality of $P$. fucata varies with latitude and populations from different genetic stocks (Wada, Kumaru, Ichimera \& Kurosaki 1995; Behzadi, Parivar \& Roustain 1997). Two spawning peaks (summer and autumn spawning) have been reported for P. fucata in Australia with latter being more consistent (Tranter 1958). Similar bimodal spawning activity has been reported for P. fucata in the Persian Gulf also (Behzadi et al. 1997).

During the present study apart from significant difference in the biometric relationships between TSK and TST, considerable variation in the slopes and intercepts were observed for the stocks grown at

Table 5 Comparison of dorso-ventral measurement (DVM) and total weight (TWT) attained after one year in different stocks of Pinctada fucata

\begin{tabular}{lllll}
\hline Location & Habitat & DVM (mm) & TWT (g) & Authors \\
\hline Gulf of Mannar & Natural bed & 44.0 & 10.0 & Devanesan and Chidambaram (1956) \\
Gulf of Kutch & Natural bed & 45.0 & - & Narayanan and Michael (1968) \\
Tuticorin Bay & Suspended culture & 47.0 & 8.3 & Chellam (1988) \\
Tuticorin Bay & Suspended culture & 45.0 & 15.0 & Velayudhan et al. (1996) \\
Kollam Bay, Arabian Sea, Transplanted stock & Suspended culture & 69.8 & 56.9 & Present study \\
Kollam Bay, Arabian Sea, Native stock & Suspended culture & 62.5 & 46.1 & Present study \\
\hline
\end{tabular}


the same place (TSK and KS). Such heterogeneity has been reported in natural populations of $P$. fucata inhabiting the different pearl oyster beds in the Gulf of Mannar (Alagarswami \& Chellam 1977) in areas where the general physical features and faunistic characters were similar. In hatchery reared spat of the same species significant difference in morphometric characters within and between the four filial generations were observed along the east coast (Velayudhan et al. 1996). Morphological differences have been observed between populations of mussels that live in relatively close proximity. Seed (1976) has concluded that changes in shell morphology in the same population are essentially due to environment factors.

In $P$. maxima culture where cost of nuclei plays a significant role in the economics of pearl production due to its large size, investigations (Knauer \& Taylor 2002) were undertaken to study the relationship between the morphological characteristics of P. maxima and the size of the nucleus that could ultimately be used. They reported that oyster wet weight was the best predictor of nuclei size. However in the case of P. fucata, thickness of the oyster is perhaps as critical as weight. The advantage of growing P. fucata in Kollam Bay in terms of increased THK, DVM and TWT has been clearly shown by this study.

The present study indicated that the environmental conditions prevailing along the southeast Arabian Sea appear to be congenial for the growth, gametogenesis, spawning and settlement of $P$. fucata larvae. In spite of strong monsoonal influences in the hydrology of Kollam Bay, the establishment of P. fucata stocks indicates its relative hardiness and ability to adapt to a changed environment. Compared with other filter feeding bivalve shellfish from tropical waters, Pinctada species grow very slowly with an annual increase in shell length of less than $3 \mathrm{~cm}$ (Yoo et al. 1986; Numaguchi 1996; Hawkins, Smith, Tan \& Yasin 1998). Pinctada species are often inhabitants of clearer waters including coral reefs as evidenced by the discontinuous distribution along the Indian subcontinent (Gulf of Mannar and Gulf of Kutch). Kollam Bay is characterized by high TSS and productivity values in comparison with the Gulf of Mannar, and therefore, the growth of the oysters to more than $6 \mathrm{~cm}$ within 1 year, could be due to the presence of abundant particulate matter and productivity. This abundance could have indirectly resulted in decreased pumping activity for feeding by the oysters, thereby conserving and utilizing this energy for somatic and shell growth.
Trying to identify the reason for overall heterogeneity of P. fucata in the Gulf of Mannar, Alagarswami and Chellam (1977) pointed out the possible role of suspension of sediments, which lead to clear and turbid waters over the oyster beds. In the present study, TSS was found to be negatively correlated with growth in Tuticorin Bay, but a similar relationship could be not be established in Kollam Bay where high TSS values prevailed. Food availability has been considered as the one of the major factors responsible for bivalve growth in suspended grow out systems (Leighton 1979). Urban (2000) did not find any environmental factor to be significantly correlated with growth but it tended to increase with increase in chlorophyll $a$ suggesting phytoplankton abundance enhanced growth in P. imbricata.

The correlation of environmental factors with growth indicated that in the Gulf of Mannar, growth was positively related to rainfall while in the southeast Arabian Sea growth was negatively correlated with rainfall. This contradiction is clearly related to the difference in intensity of rain at these two sites. While Tuticorin Bay receives very meager rainfall during the winter monsoon, the same is bimodal (winter and summer monsoon) and high in Kollam Bay. The monsoon rains in Kollam Bay brings about fluctuations in physico-chemical parameters, particularly, temperature, salinity, TSS, phosphate and net productivity. These fluctuations are a likely reason for the negative correlation observed presently. While at Tuticorin, the hydrological parameters were relative stable, and not influenced by the weak winter monsoon.

Temperature has been identified as a critical environmental variable affecting the distribution of pearl oysters (Yukihira, Lucas \& Klumpp 2002) and several studies have identified temperature as one of the main factors affecting the growth of pearl oysters (Gervis and Sims 1992). In Kollam Bay alone, temperature and phosphate content were positively correlated to growth, though the temperature range in both the bays were almost similar (25.2-31.4 Tuticorin Bay and $24-31{ }^{\circ} \mathrm{C}$ Kollam Bay). Gokhale et al. (1954) based on the analysis of growth rings identified a period of fast growth and a rest period for P. fucata in the Gulf of Kutch. They indicated low temperature ranging between 23 and $27^{\circ} \mathrm{C}$ favorable for growth and cessation of growth during summer months when temperature is high. The warmer Queensland waters were found to promote growth in the P. fucata during the nursery and grow-out phases (O'Connor 2002). Temperature effects on suspension feeding, physiolo- 
gical parameters and scope for growth indicated that there would be marked seasonal variations in growth in P. margaritifera and P. maxima in environment where water temperatures vary seasonally (Yukihira et al. 2002). In Kollam Bay water temperatures showed marked variation coinciding with the monsoon, while at Tuticorin Bay water temperatures remained consistently high in most of the months.

This study clearly indicates that the growing environment strongly influences the growth pattern and biometric relationships in the pearl oyster P. fucata. Further it also indicates that there is considerable advantage in growing P. fucata spat along the southwest coast of India to produce pearl oysters with larger thickness, weight and DVM which are more suitable for insertions of more than $6 \mathrm{~mm}$ diameter pearl nucleus.

\section{Acknowledgments}

The authors are grateful to the Director, Central Marine Fisheries Research Institute (CMFRI), Cochin for facilities and encouragement. They are thankful to the technical and supporting staff and research scholars of the Molluscan Fisheries Division for technical help. Pearl oyster spat used in the study were supplied by the Shellfish Hatchery of Tuticorin Research Centre of CMFRI. Comments by an anonymous referee greatly helped to improve the manuscript, for which the authors are thankful. The study was funded by the National Agricultural Technology Project (NATP) of the World Bank (Grant No. 2090000004) which is gratefully acknowledged.

\section{References}

Alagarswami K. (1991) Production of Cultured Pearls. Indian Council of Agricultural Research, New Delhi, India.

Alagarswami K. \& Chellam A. (1977) Change of form and dimensional relationship in the pearl oyster Pinctada fucata from Gulf of Mannar. Indian Journal of Fisheries 24, 1-14.

Alagarswami K. \& Victor A.C.C. (1976) Salinity tolerance and rate of filtration of the pearl oyster, Pinctada fucata. Journal of the Marine Biological Association of India 18, 149-158.

Beaubrun P.C. (1972) Attempts at introducing two new breeding mollusks to Morocco. Bulletin Institut Peches Maritime Morocco 20, 111-119.

Behzadi S., Parivar K. \& Roustain P. (1997) Gonadal cycle of the pearl oyster Pinctada fucata (Gould) in Northeast Persian Gulf, Iran. Journal of Shellfish Research 16, 129-135.
Chacko P.I. (1970) The pearl fisheries of Madras state. In: Proceedings of the Symposium on Mollusca Part III (ed. by R.W. Dexter), pp. 868-872. Marine Biological Association of India, Cochin, India.

Chellam A. (1978) Growth of pearl oyster Pinctada fucata in the pearl culture farm at Veppalodai. Indian Journal of Fisheries 25, 77-83.

Chellam A. (1988) Growth and biometric relationship of pearl oyster Pinctada fucata (Gould). Indian Journal of Fisheries 35, 1-6.

Chellam A., Velayudhan T.S. \& Victor A.C.C. (1987) Pearl oyster farming. In: Pearl Culture. Bulletin Central Marine Fisheries Research Institute, Vol. 39 (ed. by K. Alargarswami), pp. 72-77. Central Marine Fisheries Research Institute, Cochin, India.

Colgan D.J. \& Ponder W.F. (2002) Genetic discrimination of morphologically similar, sympatric species of pearl oysters (Mollusca: Bivalvia: Pinctada) in eastern Australia. Australian Journal of Marine and Freshwater Research $\mathbf{5 3}$, 697-709.

Devanesan D.W. \& Chidambaram K. (1956) Results obtained at the pearl oyster farm, Krusadai Island, Gulf of Mannar and their application to problems relating to pearl fisheries in the Gulf of Mannar. Contribution from the Marine Fisheries Biological Station, Krusadai Island, Gulf of Mannar 4, 1-89.

Gervis M.H. \& Sims N.A. (1992) The biology and culture of pearl oysters (Bivalvia: Pteridae) ICLARM Studies and Reviews, 21. Overseas Development Administration, UK and ICLARM, Manila. 49pp.

Gokhale S.V., Easwaran C.R. \& Narasimhan R. (1954) Growth-rate of the pearl oyster (Pinctada fucata) in the Gulf of Kutch with a note on the pearl fishery of 1953. Journal of Bombay Natural History Society 52, 124-136.

Hawkins A.J.S., Smith R.F.M., Tan S.H. \& Yasin Z.B. (1998) Suspension-feeding behaviour in tropical bivalve molluscs: Perna viridis, Crassostrea belecheri, Crassostrea iradelei, Saccostrea cucullata and Pinctada margaritifera. Marine Ecology Progress Series 166, 173-185.

Hopkins K.D. (1992) Reporting fish growth: a review of the basics. Journal of World Aquaculture Society 23, 173-179.

Hynd J.S. (1955) A revision of Australian pearl shells, Genus Pinctada. Australian Journal of Marine and Freshwater Research 6, 98-137.

Kafuku T. \& Ikenoue H. (1983) Pearl oyster (Pinctada fucata). In: Modern Methods of Aquaculture in Japan (ed. by H. Ikenoue \& T. Kafuku), pp. 161-171. Developments in Aquaculture and Fisheries Science, Elsevier Science Publishing Co., Amsterdam, the Netherlands.

Kautsky N., Johannesson K. \& Tendengren M. (1990) Genotypic and phenotypic differences between Baltic and North Sea populations of Mytilus edulis evaluated through reciprocal transplantations. I. Growth and morphology. Marine Ecology Progress Series 59, 203-210.

Kawamoto N.Y. \& Motoki E. (1954) Influence of diluted seawater on the pearl oyster Pinctada martensii (Dunker). 
Reprints Faculty of Fisheries Prefecture University of Mie 1, 346-354.

Knauer J. \& Taylor J.J.U. (2002) Assessment of external growth parameters of the silver or goldlip pearl oyster Pinctada maxima as indicators of the required pearl nucleus size (abstract). SPC Pearl Oyster Information Bulletin 15, 31 .

Kripa V., Mohamed K.S., Velayudhan T.S., Radhakrishnan P., Alloycious P.S., Mohan A. \& Appukuttan K.K. (2003) Production of 6 to $8 \mathrm{~mm}$ marine pearls in the pearl oyster Pinctada fucata (Gould) from southwest coast of India. In: Book of Abstracts. First Indian Pearl Congress and Exposition (5-8 February 2003), pp. 76-77. Central Marine Fisheries Research Institute, Cochin, India.

Leighton D.L. (1979) A growth profile for the rock scallop Hinnites multirugosus held at several depths off La Jolla, California. Marine Biology 51, 229-232.

Lodeiros C., Pico D., Prieto A., Narvaez N. \& Guerra A. (2002) Growth and survival of the pearl oyster Pinctada imbricata (Roding 1758) in suspended and bottom culture in the Golfo de Cariaco, Venezuela. Aquaculture International 10, 327-338.

Mallet R.K. \& Carver C.E.A. (1989) Growth, mortality and secondary production in the natural populations of the blue mussel Mytilus edulis. Canadian Journal of Fisheries and Aquatic Sciences 46, 1154-1159.

Mohammad M.B.M. (1976) Relationship between biofouling and growth of the pearl oyster Pinctada fucata (Gould) in Kuwait, Arabian Gulf. Hydrobiologia 51, 129-138.

Nair P.V.R. \& Gopinathan C.P. (1981) Productivity of the exclusive economic zone of India. Journal of the Marine Biological Association of India 23, 48-54.

Narayanan K.R. \& Michael M.S. (1968) On the relationship between age and linear measurements of the pearl oyster, Pinctada vulgaris (Schumacher), of the Gulf of Kutch. Journal of the Bombay Natural History Society 65, 441-452.

Nasr D.H. (1984) Feeding and growth of the pearl oyster Pinctada margaritifera in Dongonab Bay, Sudan, Red Sea. Hydrobiologia 110, 241-246.

Nayar K.N., Mahadevan S., Ramadoss K., Sundaram N. \& Rajan C.T. (1978) Experimental study of the settlement and collection of the spat of the pearl oyster from Tuticorin area. Indian Journal of Fisheries 25, 246-252.

Numaguchi K. (1996) A review on the feeding ecology and food environment of the Japanese pearl oyster, Pinctada fucata martensii. Bulletin of National Research Institute of Fisheries Science 8, 123-128.

Numaguchi K. \& Tanaka Y. (1986a) Effects of salinity on the mortality and growth of the spat of the pearl oyster Pinctada fucata martensii. Bulletin of National Research Institute of Aquaculture (Japan)/Yoshokukenho 9, 41-44.

Numaguchi K. \& Tanaka Y. (1986b) Effects of temperature on the mortality and growth of the spat of the pearl oyster Pinctada fucata martensii. Bulletin of National Research Institute of Aquaculture (Japan)/Yoshokukenho 9. 35-39.
O'Connor W. (2002) Abstracts, reviews and current contents. SPC Pearl Oyster Information Bulletin 15, 23-27.

Pandya J. (1975) Age and growth of the pearl oyster, Pinctada vulgaris (Schumacher), of the Gulf of Kutch. Journal of the Indian Fisheries Association 2, 47-54.

Pandya J. (1976) Influence of temperature on the growth ring formation in the pearl oyster Pinctada fucata (Gould) of the Gulf of Kutch. Indian Journal of Marine Science $\mathbf{5}$, 249-251.

Pass D.A., Dybdahl R. \& Mannion M.M. (1987) Investigations into the causes of mortality of the pearl oyster Pinctada maxima (Jameson), in Western Australia. Aquaculture 65 , 149-169.

Pit J.H. \& Southgate P.C. (2003) Fouling and predation: how do they affect growth and survival of the blacklip pearl oysters, Pinctada margaritifera, during nursery culture? Aquaculture International 11, 545-555.

Rajagopalan M. \& Krishnakumar P.K. (2003) Environment and forecasting. In: Status of Exploited Marine Fishery Resources of India (ed. by M.J. Modayil \& A.A. Jayaprakash), pp. 291-298. Central Marine Fisheries Research Institute, Cochin, India.

Saville-Kent W. (1905) Torres Straits pearl shell fisheries. pp. 1075-1978 In: Queensland Parliamentary Papers: Session 2 of 1905 Report of both Houses of Parliament (ed. by D.H. Borchardt), Vol. 2. Government Printer, Brisbane.

Seed R. (1976) Ecology. In: Marine Mussels:Their Ecology and Physiology (ed. by B.L. Bayne), pp. 13-65. Cambridge University Press, Cambridge.

Snedecor G.W. \& Cochran W.G. (1967) Statistical Methods. The Iowa State University Press, USA.

Stirling H.P. \& Okumus I. (1994) Growth, mortality and shell morphology of cultivated mussel (Mytilus edulis) stocks cross-planted between two Scottish sea lochs. Marine Biology 119, 115-123.

Strickland J.D.H. \& Parsons T.R. (1972) A practical handbook of Seawater analysis. Bulletin Fisheries Research Board of Canada 167, 1-310.

Tranter D.J. (1958) Reproduction in Australian pearl oysters (Lamellibranchia) III. Pinctada albina (Lamarck): breeding season and sexuality. Australian Journal of Marine and Freshwater Research 9, 144-158.

Tranter D.J. (1959) Reproduction in Australian pearl oysters (Lamellibranchia) V. Pinctada fucata (Gould): breeding season and sexuality. Australian Journal of Marine and Freshwater Research 10, 45-66.

Urban H. (2000) Culture potential of the pearl oyster (Pinctada imbricata) from the Caribbean. II. Spat collection and growth and mortality in culture systems. Aquaculture 189, 375-388.

Velayudhan T.S., Chellam A., Dharmaraj S., Victor A.C.C. \& Kasim H.M. (1996) Comparison of growth and shell attributes of four generations of pearl oyster Pinctada fucata (Gould) produced in the hatchery. Indian Journal of Fisheries 43, 69-77. 
Velayudhan T.S., Kripa V. \& Alloycious P.S. (1999) Pearl culture experiment along Kerala coast. In: Proceedings of the Fourth Indian Fisheries Forum (ed. by M.J. Modayil), pp. 179-181. Indian Fisheries Forum, Mangalore, India.

Wada K.T. (1984) Breeding study of the pearl oyster Pinctada fucata. Bulletin of National Research Institute of Aquaculture. (Japan)/Yoshokukenho 6, 79-157.

Wada K.T., Kumaru A., Ichimera Y. \& Kurosaki H. (1995) Spawning peak occurs during winter in the Japanese sub- tropical populations of the pearl oyster Pinctada fucata (Gould, 1850). Aquaculture 133, 207-214.

Yoo S.K., Chang Y.J. \& Lim H.S. (1986) Growth comparison of pearl oyster Pinctada fucata between the two culturing areas. Bulletin of Korea Fisheries Society 19, 593-598.

Yukihira H., Lucas J.S. \& Klumpp D.W. (2002) Comparative effects of temperature on suspension feeding and energy budgets of the pearl oysters Pinctada margaritifera and $P$. maxima. (Abstract). SPC Pearl Oyster Information Bulletin $15,35$. 